\title{
Інтеграція освіти, науки та виробництва в системі підготовки агроінженерів до інноваційної проектної діяльності на засадах вчення акад. П.М. Василенка
}

\author{
В.М. Пришляк \\ Вінницький національний аграрний університет (м.Вінниця, Україна) \\ email: viktor.prishlyak@i.ua; ORCID:0000-0001-6992-9211
}

\begin{abstract}
У статті висвітлено результати наукових досліджень розвитку інноваційних технологій підготовки майбутніх фахівців з агроінженерії до проектної діяльності. Під час проведення наукових досліджень виявлено та проаналізовано основні фактори зростання якісних показників навчання й формування професійних компетентностей агроінженерів відповідно до вимог, передбачених стандартами освіти. Встановлено вплив, а також ефективність інтеграції аграрної освіти, науки та виробництва в системі підготовки агроінженерів до інноваційної проектної діяльності на формування професійних компетентностей майбутніх фахівців, їх знання теорії робочих процесів, необхідних для високоефективного функціонування агропромислового виробництва, проведення наукових досліджень, спрямованих на вдосконалення існуючих і створення нових машин на засадах вчення акад. П.М. Василенка.

Процес підготовки агроінженера до проектної діяльності ускладнюється тим, що об’єктом дії машин, знарядь і механізмів аграрної галузі є об'єкти, матеріали, середовища з різноманітними механіко-технологічними, агротехнічними та зооветеринарними властивостями. Тобто, як правило, об'єктами є біологічно живі організми, а тому переносити форми і методи педагогічних технологій з промисловості, машинобудування, будівельної чи транспортної інженерії інколи не ефрективно і недоцільно. Потрібні нові наукові підходи із широкомасштабним залученням науково складової, котрі максимально зорієнтовані на об'єкти виробничої діяльності майбутніх агроінженерних фрахівців. Сучасний, підготовлений на науковій основі, із знанням особливостей агропромислового виробництва агроінженер - це ключовий суб'єкт технічного забезпечення технологічних процесів рослинництва, тваринництва та переробної галузі.

Технічному забезпеченню агропромислового виробництва, а особливо, творчій проектній діяльності П.М. Василенко приділяв велике значення. Він вважав, що першочерговим у проектуванні та конструюванні машин повинні бути фундаментальні знання із технологій землеробства, агрофрізичних і механіко-технологічних властивостей с.-г. матеріалів як об'єктів, з якими взаємодіють робочі органи машин, змінюючи їх стан, характеристики, положення тощо. Інтеграція аграрної освіти, науки та виробництва в системі підготовки агроінженерів до інноваційної проектної діяльності на засадах вчення акад. П.М. Василенка позитивно впливає на формування професійних компетентностей майбутніх фрахівців агропромислового комплексу. Саме через таку кооперацію можливе суттєве зростання валового національного продукту, збільшення та розширення експортного потенціалу країни, поліпшення фрінансово-економічного та соціального рівня життя людей.
\end{abstract}

Ключові слова: інтеграція, освіта, наука, виробництво, проектна діяльність, землеробська механіка.

Постановка проблеми. Високоякісна підготовка фрахівців з агроінженерії відповідно до вимог стандартів освіти можлива в інтегральній взаємодії основних компонентів соціально-економічного інноваційного фрункціонування агропромислового комплексу. Завдання будь-якого виробництва полягає у досягненні позитивних економічних показників, які забезпечують функціонування системи у складному конкурентному середовищі. Забезпечити економічний розвиток системи спроможні фрахівці, котрі мають фундаментальну базову загальнотеоретичну підготовку, здатні до саморозвитку та самовдосконалення і спроможні виявляти недоліки технологічних процесів агропромислового виробництва (АПВ) та вирішувати їх на науковій основі.
Вчення акад. П.М. Василенка базується на фундаментальних засадах науки, освіти та виробництва. Не викликає сумніву той фракт, що розробка сучасної с.-г. техніки та раціональних технологічних процесів можлива тільки на основі теоретичних розрахунків, оптимізації параметрів об'єктів. А тому застосування теоретико-методологічних засад вчення акад. П.М. Василенка $€$ важливим та актуальним у педагогічних технологіях підготовки майбутніх агроінженерів до інноваційної проектної діяльності, фоомування інтегральної, загальних і професійних компетентностей відповідно до стандарту освіти [1], що $€$ базовою основою розвитку землеробської механіки загалом. 
Аналіз останніх досліджень. Значний вклад у розвиток наукових основ фундаментальної аграрної освіти, науки та виробництва вніс акад. П.М. Василенко. Ним опубліковано низку фундаментальних монографій із землеробської механіки, теорії, розрахунку та проектування с.-г. машин, автоматизації с.-г. виробництва, наприклад, [2, 3, 4, 5, 6]. У монографії за ред. С.М. Ніколаєнка [7] відображено основні етапи життя, науково-дослідницьку та педагогічну діяльність П.М. Василенка - видатного вченого в галузі механізації, автоматизації та с.-г. машинознавства. Великий науковий, освітянський і виробничий інтерес викликають отримані ним результати фундаментальних досліджень в галузі динаміки і стійкості руху с.-г. машин, а також з питань теорії та методів розрахунку ґрунтообробних, посівних, зернозбиральних і бурякозбиральних машин й машин післязбирального обробітку с.-г. продукції. Всесвітньо відома наукова праця П.М. Василенка «К теории качения колеса со следом», а у монографії [8] Булгаковим В.М. і Головачем І.В. представлено детальний аналіз і коментарі до цієї статті. У цій же монографії [8] представлено також статті учнів і послідовників наукового напряму Василенка П.М., а саме: Булгакова В.М., Калетніка Г.М., Головача І.В., Адамчука В.В., Пилипаки С.В., Тіщенка Л.М., Надитка В.Т., Паламарчука І.П., Мельника В.І., Бориса М.М., Пришляка В.М.

Як зазначено у збірнику тез доповідей XIX Міжнародної наукової конференції "Сучасні проблеми землеробської механіки" [9], академік П.М. Василенко велике значення приділяв математичній підготовці майбутніх агроінженерів, що передбачає уміння сучасного інженера будувати математичні моделі виробничих процесів, застосовувати математичні методи, розв'язуючи різноманітні прикладні задачі землеробської механіки.

Стаття [10] «До побудови математичної моделі руху по схилових землях самохідної машини зі стабілізуючим пристроєм» є прикладом застосування методології [4], розробленої акад. П.М. Василенко для описання процесу руху с.-г. машини в умовах складного рельєфу місцевості.

Базовою основою будь-якої науки $€$ понятійно-термінологічний категоріальний апарат. Сутність терміну «інтеграція» розглядалась багатьма вченими. Так, наприклад, Пугач А.М. у статті «Інтеграційні процеси в сфері аграрної освіти, науки та виробництва як визначальна умова розвитку аграрного ресурсного потенціалу України» досліджував поняття «інтеграція» та «інтеграційні процеси». Пугач А.М. зазначає, що інтеграція - сукупність взаємодії узгодженості, координованості в діях між елементами соціальної системи, що забезпечує її внутрішню єдність, цілісність, гармонійне функціонування, стійкість і динамічну стабільність [11]. У своїх працях су- часні дослідники поняттю «інтеграція» приділили і продовжують приділяти досить значну увагу. Вознюк О.В. розглядає головні аспекти педагогічної інтеграції як наукового напряму до побудови інтегративної педагогічної парадигми [12], котра спроможна забезпечити впровадження в освітню галузь синтетичного знання, що ґрунтується на основі комплексних трансдисциплінарних наукових дисциплін [12]. Забезпечення органічного поєднання освітньої, наукової та інноваційної діяльності - одне із основних завдань закладу вищої освіти [13].

Мета досліджень. Встановити вплив інтеграції аграрної освіти, науки й виробництва в системі підготовки агроінженерів до інноваційної проектної діяльності на формування професійних компетентностей майбутніх фахівців, їх знання теорії робочих процесів, необхідних для високоефективного функціонування АПВ, проведення досліджень, спрямованих на вдосконалення існуючих і створення нових машин на засадах вчення акад. П.М. Василенка, що сприятиме зростанню економічних показників і розвитку землеробської механіки.

Результати досліджень. Основним завданням сучасного АПВ у нашій державі $€$ забезпечення населення екологічно чистими, високоякісними продуктами харчування, а промисловість - різноманітною, придатною до переробки біосировиною рослинного та тваринного походження. Відомо, що Україна має великі потенціальні можливості щодо розвитку агропромислового сектора, оскільки у нас чудові родючі землі, оптимальний клімат і погодні умови, працьовиті сільгосптоваровиробники, котрі люблять землеробство, свою справу, уміють вирощувати високі врожаї, досягати значних показників у сільськогосподарському виробництві. Щорічна частка аграрного сектора економіки у валовому внутрішньому продукті України зростає і становить близько $30 \%$. Стратегія розвитку АПВ передбачає широкомасштабний розвиток науки і впровадження найкращих її досягнень у виробництво та навчальний процес. Варто зазначити, що Міністерство освіти і науки України підтримує та стимулює творчий пошук науково-педагогічних колективів та окремих викладачів і науковців. Національна доктрина розвитку освіти і науки в Україні передбачає зростання частки наукової діяльності викладачів у закладах вищої освіти (ЗВО) та збільшення кількісних, якісних і економічних показників інтеграції освіти, науки та виробництва.

Вимоги до професійних та компетентністноособистісних якостей фахівців з вищою освітою постійно зростають, оскільки стрімкий розвиток наукового-технічного прогресу у всіх сфрерах економіки та соціального життя людей ставить нові, все вагоміші запити до професійних можливостей дипломованих бакалаврів і магістрів у тій чи 
іншій галузі в конкурентному ринковому середовищі. Забезпечити високу якість підготовки фахівців з вищою освітою можна за рахунок раціональної організації освітнього процесу. У статті 47 Закону України «Про вищу освіту» зазначено, що освітній процес - це інтелектуальна, творча діяльність у сфрері вищої освіти і науки, що провадиться у ЗВО через систему науково-методичних і педагогічних заходів та спрямована на передачу, засвоєння, примноження і використання знань, умінь та інших компетенцій у осіб, які навчаються, а також на фрормування гармонійно розвиненої особистості [13].

Аналізуючи актуальні питання освітнього процесу, слід зазначити, що в умовах глобальних світових інтеграційних процесів найважливішими завданнями $€$ якісне вдосконалення структури, змісту, форм підготовки фрахівців у ЗВО, розробка інноваційних педагогічних технологій навчання та їх інформаційно-предметного забезпечення [14]. Проте, як зазначає проф. Чернілевський Д.В. успішне вирішення згаданих освітянських проблем можливе лише за умови високої професійної компетенції, творчої ініціативи та відповідальності всіх дійових осіб педагогічної системи й учасників освітнього процесу.

У Законі України «Про вищу освіту» (розділі XI, стаття 65) зазначено, що науково-технічна та інноваційна діяльність у 3ВО є невід'ємною складовою освітньої діяльності і провадиться з метою інтеграції наукової, освітньої і виробничої діяльності в системі вищої освіти [13]. Суб'єктами наукової, науково-технічної та інноваційної діяльності є працівники 3ВО, науково-дослідних установ і підприємств, особи, котрі навчаються в ЗВО. Метою такої діяльності $€$ здобуття нових наукових досягнень шляхом проведення теоретичних і експериментальних досліджень, технічних розробок, а також спрямування отриманих результатів наукової діяльності на створення і впровадження нових конкурентоспроможних технологій, машин і обладнання на забезпечення інноваційного науково-технічного, економічного розвитку суспільства, підготовку фахівців, які відповідають високим вимогам світового ринку праці. Передбачається, що новітні досягнення університетської та академічної науки відбуватимуться із широкомасштабним залученням студентів до науково-практичної діяльності, а кращі розробки впроваджуються в навчальний процес та виробництво.

У статті 66 Закону України «Про вищу освіту» зазначено, що інтеграція науково-технічної та інноваційної діяльності 3ВО і наукових установ Національної академії наук України, національних галузевих академій наук здійснюється з метою розроблення та виконання пріоритетних наукових програм, проведення наукових досліджень, експериментальних розробок тощо на засадах поєднання кадрових, фінансових і технічних ресурсів. Основні напрями інтеграції інноваційної науково-технічної діяльності 3ВО та наукових установ академій наук представлено в табл. 1.

Таблиця 1 Пріоритетні напрями інтеграції аграрної науки, освіти та виробництва, сорормовані на основі [14]

\begin{tabular}{|c|c|}
\hline $\begin{array}{l}\text { № } \\
\Pi / \Pi\end{array}$ & $\begin{array}{c}\text { Напрями інтеграції освіти, } \\
\text { науки та виробництва }\end{array}$ \\
\hline 1 & $\begin{array}{l}\text { Участь у розробці та виконанні державних і } \\
\text { регіональних програм агротехнічного, еко- } \\
\text { номічного та соціального розвитку. }\end{array}$ \\
\hline 2 & $\begin{array}{l}\text { Проведення спільних науково-практичних за- } \\
\text { ходів, теоретичних і експериментальних до- } \\
\text { сліджень на засадах ефективного фінансо- } \\
\text { вого поєднання інтеграційного потенціалу } \\
\text { освіти, науки та агробізнесу. }\end{array}$ \\
\hline 3 & $\begin{array}{l}\text { Участь у створенні інноваційних структур, тво- } \\
\text { рчих колективів та інших організаційних форм } \\
\text { кооперації, котрі здатні проводити ефективні } \\
\text { науково-технічні дослідження, проектувати } \\
\text { конкурентоспроможні агротехнології, сільсь- } \\
\text { когосподарських машини й обладнання. }\end{array}$ \\
\hline 4 & $\begin{array}{l}\text { Ефективне впровадження у навчальний про- } \\
\text { цес і виробництво спільно створених власних } \\
\text { і найкращих світових інноваційних продуктів. }\end{array}$ \\
\hline 5 & $\begin{array}{l}\text { Ефективність та своєчасність оформлення } \\
\text { патентної документації } 3 \text { охорони і захисту } \\
\text { прав інтелектуальної власності результатів } \\
\text { науково-технічної діяльності. }\end{array}$ \\
\hline 6 & $\begin{array}{l}\text { Провадження спільної видавничої та інфор- } \\
\text { маційно-ресурсної діяльності з механізованих } \\
\text { технологічних процесів виробництва, переро- } \\
\text { бки, зберігання, транспортування та контролю } \\
\text { якості продукції відповідно до конкретних ви- } \\
\text { робничих умов. }\end{array}$ \\
\hline 7 & $\begin{array}{l}\text { Залучення науково-педагогічних працівників } \\
\text { (НПП) 3ВО, наукових співробітників галузевих } \\
\text { наукових установ на основі трудового дого- } \\
\text { вору чи контракту для провадження освітньої } \\
\text { і наукової діяльності, зокрема, до підготовки } \\
\text { та експертизи підручників, посібників, освітніх } \\
\text { програм і т.п. }\end{array}$ \\
\hline 8 & $\begin{array}{l}\text { Організація на базі наукових установ і органі- } \\
\text { зацій національних галузевих академій наук } \\
\text { наукових досліджень молодих вчених, докто- } \\
\text { рантів та аспірантів, систематичної виробни- } \\
\text { чої практики студентів ЗВО із забезпеченням } \\
\text { їх безпосередньої участі у проведенні науко- } \\
\text { вих досліджень. }\end{array}$ \\
\hline 9 & $\begin{array}{l}\text { Економічне заохочення підприємств різних } \\
\text { форм власності до співпраці з ЗВО щодо ви- } \\
\text { конання науково-інноваційних проектів, підго- } \\
\text { товки і перепідготовки фахівців з вищою осві- } \\
\text { тою, проведення практики студентів. }\end{array}$ \\
\hline
\end{tabular}

Джерело: побудовано автором на основі [13]

Розвиток аграрної освіти, що відповідав би найкращим світовим досягненням підготовки агроінженерних кадрів до інноваційної проектної 
діяльності повинен базуватись на науково обґрунтованій, гуманістичній, соціально-орієнтованій основі із застосуванням інформаційних технологій та фундаментальних розробок вчених як нашої держави, так і інших розвинутих країн світу.

Завдання, поставлені в основу змісту освіти, передбачають розробку та впровадження у навчальний процес педагогічних технологій, котрі $€$ гнучкими, мобільними та легко адаптованими до впровадження у педагогічні технології навчання сучасних досягнень науки і техніки й відповідати потребам виробництва, мати практичне застосування. Системно інтегровані, інноваційні технології навчання передбачають розвиток творчої пізнавальної активності суб'єктів навчання - майбутніх агроінженерів, фрормування у них здатності до інноваційної проектної діяльності, оскільки вона $є$ базовою основою для виконання практично усіх видів робіт на виробництві та допомагає у соціальній сфрері. Саме інноваційна проектна діяльність забезпечує розробку новітніх конкурентоспроможних технологій, сучасних сільськогосподарських машин та агрегатів, обладнання переробної галузі, транспортуючих систем і механізмів.

Перед національною вищою аграрною освітою стоять завдання підготовки фахівців, які спроможні в сучасних умовах швидко та оперативно реагувати на наукові, економічні та соціальні зміни. Підготовка сучасного агроінженера - досить складний і багатогранний процес. Сфрормувати загальні компетенції майбутнього агроінженера із ґрунтовного знання законів механіки, загально-інженерних дисциплін, які направлені на розвиток аналітичного та фрахово-орієнтовного мислення спеціаліста, котрий спроможний аналізувати та систематизувати процеси та явища агропромислового виробництва, диференціювати, відтворювати, прогнозувати, кількісно та якісно оцінювати стан виробництва - усе це є складними та відповідальними завданнями освітянської діяльності, головним завданням НПП ЗВО.

Кваліфікаційні вимоги щодо професійних компетентностей агроінженера суттєво відрізняється від професійних компетентностей інженерів промислової групи. Процес підготовки агроінженера до проектної діяльності ускладнюється тим, що об'єктом дії машин, знарядь і механізмів аграрної галузі є об'єкти, матеріали, середовища з різноманітними механіко-технологічними, агротехнічними та зооветеринарними властивостями. Тобто, як правило, об'єктами є біологічно живі організми, а тому переносити форми і методи педагогічних технологій з промисловості, машинобудування, будівельної чи транспортної інженерії інколи не ефективно і недоцільно. Потрібні нові наукові підходи із широкомасштабним залученням наукової складової, котрі максимально зорієнтовані на об'єкти виробничої діяльності майбутніх агроінженерних фрахівців. Сучасний, підготовлений на науковій основі, із знанням особливостей агропромислового виробництва агроінженер - це ключовий суб'єкт технічного забезпечення технологічних процесів рослинництва, тваринництва та переробної галузі.

Високоякісну підготовку агроінженерних кадрів у значній мірі забезпечує інтеграція аграрної освіти, науки та виробництва. У стандарті вищої освіти, затвердженого наказом Міністерства освіти і науки України (№ 1340, від 05.12.2018) [1], представлено спеціальні компетентності, котрі повинні бути сформованими у майбутнього агроінженера у результаті навчального процесу. Деякі з них наведено в табл. 2.

Таблиця 2 Деякі спеціальні компетентності агроінженера [1], що повинні бути

сорормованими під час навчального процесу

\begin{tabular}{|c|c|}
\hline № & Спеціальні компетентності агроінженера \\
\hline 1 & $\begin{array}{l}\text { Здатність використовувати комп'ютерне про- } \\
\text { грамне забезпечення для застосування моде- } \\
\text { лей, що виникають в агроінженерній практиці, і } \\
\text { проведення розрахунків за такими моделями. }\end{array}$ \\
\hline 2 & $\begin{array}{l}\text { Здатність використовувати основи агрономії і } \\
\text { тваринництва для обґрунтування механізова- } \\
\text { них технологічних процесів сільськогоспо- } \\
\text { дарського виробництва. }\end{array}$ \\
\hline 3 & $\begin{array}{l}\text { Здатність використовувати основи механіки } \\
\text { твердого тіла і рідини, матеріалознавства і мі- } \\
\text { цності матеріалів для опанування будови, } \\
\text { принципу роботи та теорії сільськогосподар- } \\
\text { ської машин. }\end{array}$ \\
\hline 4 & $\begin{array}{l}\text { Здатність до конструктивно мислення на ос- } \\
\text { нові побудови графрічних моделей просторо- } \\
\text { вих форм, проектування деталей машин і ме- } \\
\text { ханічних систем з використанням інструментів } \\
\text { автоматизованого проектування, методів і за- } \\
\text { собів технічних вимірювань й оцінювання по- } \\
\text { хибок, задач і принципів стандартизації. }\end{array}$ \\
\hline 5 & $\begin{array}{l}\text { Здатність використовувати основи термоди- } \\
\text { наміки і гідравліки для визначення і вирішення } \\
\text { інженерних завдань з використанням типових } \\
\text { методів. }\end{array}$ \\
\hline 6 & $\begin{array}{l}\text { Здатність обирати і використовувати механі- } \\
\text { зовані технології виробництва, переробки, } \\
\text { зберігання, транспортування та контролю яко- } \\
\text { сті продукції відповідно до конкретних умов с.- } \\
\text { г. виробництва. }\end{array}$ \\
\hline 7 & $\begin{array}{l}\text { Здатність визначати та аналізувати технічні й } \\
\text { експлуатаційні параметри с.-г. техніки, її меха- } \\
\text { нізмів, систем і вузлів, обґрунтовувати ре- } \\
\text { жими роботи та комплектувати сільськогоспо- } \\
\text { дарські агрегати. }\end{array}$ \\
\hline 8 & $\begin{array}{l}\text { Здатність організовувати використання техніки } \\
\text { відповідно до вимог і принципів оптимального } \\
\text { природокористування й охорони природи. }\end{array}$ \\
\hline 9 & $\begin{array}{l}\text { Здатність аналізувати та систематизувати на- } \\
\text { уково-технічну інформацію для організації ма- } \\
\text { теріально-технічного забезпечення АПК. }\end{array}$ \\
\hline 10 & $\begin{array}{l}\text { Здатність проводити економічне обґрунтування } \\
\text { доцільності застосування технологій в АПВ, за- } \\
\text { ходів з підтримання МТП у належному стані. }\end{array}$ \\
\hline
\end{tabular}

Джерело: побудовано автором на основі [1] 
Великий вклад у розвиток інноваційної проектної діяльності агроінженерів й системних інтеграційних процесів аграрної науки, освіти та виробництва вніс акад. П.М. Василенко (рис. 1).

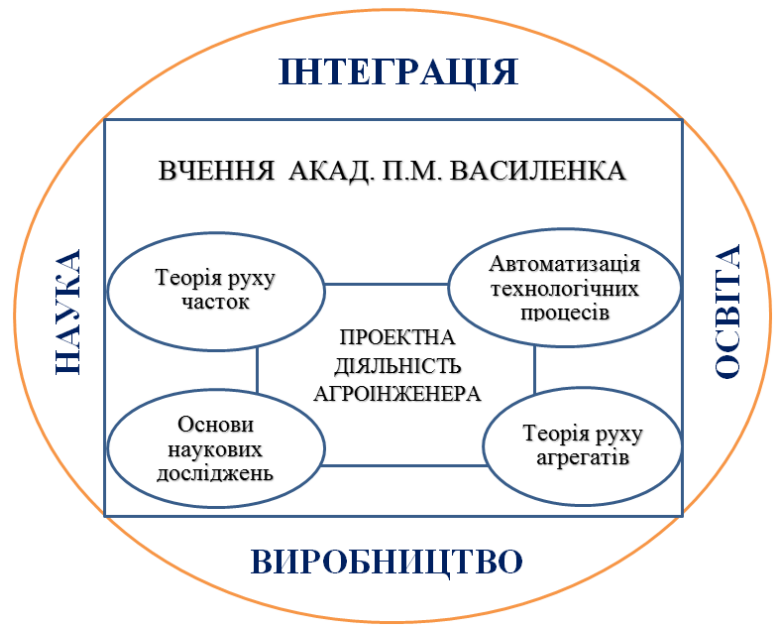

Рис. 1. Взаємозв'язок і вплив вчення акад.

П.М. Василенка на розвиток проектної діяльності агроінженерів та інтеграційні процеси науки, освіти та виробництва

Технічному забезпеченню АПВ, а особливо, творчій проектній діяльності П.М. Василенко приділяв велике значення. Він вважав, що першочерговим у проектуванні та конструюванні машин повинні бути фундаментальні знання із технологій землеробства, агрофрізичних і механіко-технологічних властивостей сільськогосподарських матеріалів як об'єктів, з якими взаємодіють робочі органи машин, змінюючи їх стан, характеристики, положення тощо. Варто зазначити, що свою викладацьку діяльність (котра завжди на його життєвому шляху була пов'язана з виробництвом та наукою, як базовою основою розвитку власне виробництва) П.М. Василенко почав на посадах учителя хімії та ґрунтознавства, землеробства, сільськогосподарського машинознавства, механізації сільськогосподарського виробництва, а також у цей час він займався питаннями практичного рільництва [7]. Пізніше вчений розробляв робочі органи сільськогосподарських машин, методики руху машино-тракторних агрегатів (MTA), автоматизацію робочих процесів, узагальнював основи наукових досліджень в галузі механізації сільського господарства.

Наукові праці акад. П.М. Василенка мають особливу цінність, оскільки вони написані на базовій основі глибоких фундаментальних знань реального сільськогосподарського виробництва 3 огляду на широкомасштабне їх використання в аграрній науці, освітній діяльності та практичному агробізнесовому середовищі. Особливий науковий інтерес викликає книга «Теория движения частицы по шероховатым поверхностям сельскохозяйственных машин» [2] призначена для нау- кових працівників, які проводять дослідження в області сільськогосподарського машинознавства, аспірантів спеціальностей машини і засоби механізації сільськогосподарського виробництва, галузеве машинобудування. У книзі [2] академіка П.М. Василенко на фундаментальному науковотеоретичному рівні проаналізував і методологічно розробив ряд проблемних засад, важливих для розвитку аграрної науки, освіти та виробництва. Деякі з них наведено у табл. 3.

Таблиця 3. Проблемні, важливі для розвитку аграрної науки, освіти та виробництва фундаментальні методологічні засади, розроблені акад. П.М. Василенком [2]

\begin{tabular}{|c|l|}
\hline $\begin{array}{c}\text { № } \\
\text { n/п }\end{array}$ & \multicolumn{1}{|c|}{$\begin{array}{l}\text { Пробллемні методологічні засади } \\
\text { розробі акад. П.М. Василенком }\end{array}$} \\
\hline 1 & $\begin{array}{l}\text { Історичні аспекти розвитку теорії руху ма- } \\
\text { теріальної точки і твердого тіла }\end{array}$ \\
\hline 2 & $\begin{array}{l}\text { Диференціальні рівняння руху матеріальної } \\
\text { частки по поверхні }\end{array}$ \\
\hline 3 & Рухчастки матеріалу по горизонтальній площині \\
\hline 4 & Рухчастки матеріалу по похилій площині \\
\hline 5 & $\begin{array}{l}\text { Рух частки матеріалу по гравітаційним кривим } \\
\text { і поверхням }\end{array}$ \\
\hline 6 & $\begin{array}{l}\text { Гравітаційні скатні поверхні, що обумовлюють } \\
\text { екстремальні значення кінематичних елемен- } \\
\text { тів руху частки }\end{array}$ \\
\hline 7 & $\begin{array}{l}\text { Явище таутохронізма при русі частки по } \\
\text { гравітаційній скатній поверхні }\end{array}$ \\
\hline 8 & Рухччастки по коливній площині \\
\hline 9 & Теорія руху частки по циліндричній поверхні \\
\hline 10 & Рух частки матеріалу по ротаційним поверхнях \\
\hline 11 & Про рухчастки по гвинтовій поверхні \\
\hline
\end{tabular}

Джерело: побудовано автором на основі [2]

Важлива роль в ефективності результату інтеграції аграрної освіти, науки та виробництва в системі підготовки агроінженерів до інноваційної проектної діяльності належить автоматизації процесів сільськогосподарського виробництва. В книзі, написаній акад. ВАСХНІЛ П.М. Василенком і канд. техн. наук И.И. Василенком [3], узагальнено на класичних засадах матеріали з автоматизації сільськогосподарського виробництва. У ній [3] викладено елементи теорії лінійних систем автоматичного регулювання та розглянуто конструкції основних автоматичних пристроїв, які призначенні для автоматизації процесів сільськогосподарського виробництва. Книга розрахована на агроінженерів та інших спеціалістів, які працюють в області автоматизації процесів агропромислового виробництва. Автори зазначають, що важливими засобами, які забезпечують технічний прогрес розвитку освіти, науки й виробництва $€$ комплексна механізація та автоматизація процесів. Зростаючими характеристиками виробництва $€$ підвищення продуктивності праці, зниження собівартості продукції та підвищення ії якості. За умов комплексної механізації на виробництві 
використовують набір машин, які без використання ручної праці послідовно виконують усі виробничі операції, тобто операції, які безпосередньо зв'язані з об'єктом праці, матеріалом, який обробляється. Що стосується керування та регулювання машин, то на час написання книги [3] (1964 рік) ці процеси проводилися вручну. Зараз, в умовах сучасного виробництва, особливо, керування машин майже повністю автоматизовано.

Сучасне, конкурентоздатне на світовому ринку сільськогосподарське виробництво потребує великої кількості різноманітних технічних засобів автоматизації. У більшості випадків ці засоби автоматизації не можуть бути запозичені з промисловості, так як вони повинні відповідати вимогам характерним для сільськогосподарського виробництва. А саме: автоматичні пристрої повинні бути прості за конструкцією, щоб можна було проводити їх наладку у польових умовах; пристосовані для роботи при наявності у повітрі великої кількості легких домішок, таких як пилу, полови та ін., а також важких - землі, піску тощо; пристосовані для роботи на рухомих машинах при змінних режимах завантаження, змінних фрізико-механічних властивостях оброблюваного матеріалу, наприклад, вологості, твердості, хімічного складу і т.п. [3].

На різних етапах розвитку науки, освіти, виробництва появлялась сільськогосподарська техніки з автоматичними пристроями, котрі відповідали вищезазначеним вимогам. Але у зв'язку із заміною конструкцій машин на нові автоматичні пристрої часто втрачають ефективність виробничого застосування, хоча в них закладено досить цінні технічні якості, що відповідали умовам тогочасного сільськогосподарського виробництва. Наприклад, стаціонарні складні молотарки, що застосовувались у 30 - 50-х роках минулого століття обладнувались досить ефективними на той час автоматичними пристроями для регулювання кількості хлібної маси, котра подається до молотильного барабану. На цих же стаціонарних молотарках застосовувались спеціальні пристрої для автоматичного зважування намолоченого зерна. Раніше практично вся солома, що надходила з молотарок скирдувалось, i, відповідно, були розроблені пристрої для подачі соломи до місць накопичення з подальшим ії скиртуванням. Із призупиненням виробництва стаціонарних молотарок, у зв'язку з переходом на збирання зернових культур самохідними зернозбиральними комбайнами, вищеназвані автоматичні пристрої перестали використовуватись у виробничих процесах [3].

Підводячи підсумок слід зазначити, що в цілому вчення акад. П.М. Василенка це фундаментальна базова основа підготовки на високому науково-теоретичному та практичному рівні майбутніх агроінженерів у ЗВО. Актуальність застосування вчення для ефективного розвитку інте- граційних процесів агропромислового комплексу з роками не знижується, а навіть навпаки зростає, оскільки це основоположна методологія оптимізації параметрів машин і технологічних процесів сільськогосподарського виробництва, а людство прагне до оптимальних конструкцій.

Висновок. Інтеграція аграрної освіти, науки та виробництва в системі підготовки агроінженерів до інноваційної проектної діяльності на засадах вчення акад. П.М. Василенка позитивно впливає на формування професійних компетентностей майбутніх фахівців агропромислового комплексу. Саме через таку кооперацію можливе суттєве зростання валового національного продукту, збільшення та розширення експортного потенціалу країни, поліпшення фінансово-економічного та соціального рівня життя людей.

\section{Література:}

1. Стандарт вищої освіти України першого (бакалаврського) рівня освіти ступеня вищої освіти - «бакалавр», галузі знань - 20 «Аграрні науки та продовольство спеціальності» - 208 «Агроінженерія» // Затверджено та введено в дію наказом Міністерства освіти і науки України від 05.12.2018, № 1340. - Режим доступу: https://mon. gov.ua/storage/app/media/vishcha-osvita/zatverdze ni\%20standarty/12/21/208-agroinzheneriya-bakalavr.

2. Василенко П.М. Теория движения частицы по шероховатым поверхностям сельскохозяйственных машин [Текст] / П.М. Василенко. - К.: УАСХH, 1960. - 289 c.

3. Василенко П.М. Автоматизация процессов сельскохозяйственного производства / П.М. Василенко, И.И. Василенко. - М.: Колос, 1964. - 384 с.

4. Василенко П.М. Методика построения расчетных моделей функционирования механических систем (машин и машинных агрегатов): Учебное пособие / П.М. Василенко, В.П. Василенко. - К.: Полиграфика, 1980. - 135 с.

5. Василенко П.М. Основы научных исследований. Механизация сельского хозяйства / П.М. Василенко, Л.В. Погорелый. - К.: Вища школа, 1985. - 266 c.

6. Василенко П.М. Введение в земледельческую механику / П.М. Василенко. - К.: Сільгоспосвіта. 1996. - 252 с.

7. Академік Василенко Петро Мефодійович корифей землеробської механіки в Україні: монографія / С.М. Ніколаєнко, В.М. Булгаков, Д.Г. Войтюк, В.В. Адамчук, Л.М. Тіщенко; за ред. С.М. Ніколаєнка. - К.: Аграрна наука, 2015. - 264 с.

8. Академік П.М. Василенко - яскравий погляд у майбутнє; за ред. В.М. Булгакова, Г.М. Калетніка. - К.: Хай-Тек Прес, 2010. - 510 с.

9. Пришляк В.М. Підготовки майбутніх фахівців з агроінженерії до інноваційної проектної діяльності на основі вчення академіка П.М. Васи- 
ленка / В.М. Пришляк // Збірник тез доповідей XIX Міжн. наук. конф. "Сучасні проблеми землеробської механіки"(17-19 жовтня 2018 року) / МОН України. Київ. 2018. - С. 16-18.

10. Пришляк В.М. До побудови математичної моделі руху по схилових землях самохідної машини зі стабілізуючим пристроєм // Вісник аграрної науки Причорномор'я, Спеціальний випуск 4 (18), Том II. - Миколаїв: МДАУ, 2002. - С. 54-59.

11. Пугач А.М. Інтеграційні процеси в сфері аграрної освіти, науки та виробництва як визначальна умова розвитку аграрного ресурсного потенціалу України // Державне управління, Інвестиції: практика та досвід, № 13-14, 2015. - С. 7477. [Електронний ресурс]. - Режим доступу: http://www.investplan.com.ua/pdf/13-

14_2015/20.pdf

12. Вознюк О.В. Педагогічна інтеграція як один із шляхів побудови цілісної педагогічної парадигми // Матеріали Міжнародної наукової конференції. - Варшава-Краків, 2010. - С. 72-80.

13. Закон України «Про вищу освіту» від 01.07.2014 р. № 1556-VII / Газета «Голос України» від 06.08.2014 р. - № 148.

14. Чернілевський Д.В. Сучасні педагогічні технології у вищій школі та їх інформаційно-предметне забезпечення / Д.В. Чернілевський // Сучасні педагогічні технології у вищій школі: наук.метод. зб. - Вінниця: ВДСГІ, 1995. - С. 3-10.

\section{References:}

1. Standard of higher education of Ukraine of the first (bachelor's) level of higher education - "bachelor", field of knowledge - 20 "Agricultural sciences and food specialties" - 208 "Agroengineering" // Approved and put into effect by order of the Ministry of Education and Science of Ukraine 05.12.2018, № 1340. Access mode: https://mon.gov.ua/storage/app/media/vishcha-osvita/zatverdzeni\%20standarty/12/21 /208-agroinzheneriya-bakalavr.

2. Vasilenko, P.M. (1960) Theory of particle motion on rough surfaces of agricultural machines. K .: UASKhN. $-289 \mathrm{p}$.

3. Vasilenko, P.M., Vasilenko, I.I. (1960) Automation of agricultural production processes. - M .: Kolos, 1964. - 384 p.
4. Vasilenko, P.M. (1980) Methods of construction of calculation models of functioning of mechanical systems (machines and machine units): Textbook / P.М. Василенко, В.П. Василенко. Kyiv: Printing. 320 p.

5. Vasilenko, P.M., Pogorelyy, L.V. (1985) Fundamentals of Scientific Research. Mechanization of agriculture. - Kyiv: Vischa school. - $266 \mathrm{p}$.

6. Vasilenko, P.M. (1996) Introduction to agricultural mechanics. Kyiv: Silgosposvita. -252 p.

7. Nikolaunko, S.M., Bulgakov, V.M., Voityuk, D.G., Adamchuk, V.V., Tishchenko, L.M. (2015) Akademik Vasilenko Petro Mefodiyovich - luminary of agricultural mechanics in Ukraine. Kyiv: Agrarna science. $264 \mathrm{p}$.

8. Academician P.M. Vasylenko - a bright look into the future; edited by V.M. Bulgakova, G.M. Kaletnika. - Kyiv: Hi-Tech Press, 2010. - 510 p.

9. Pryshlyak, V.M. (2018) Preparation of future specialists in agroengineering for innovative design activities based on the teachings of Academician P.M. Vasylenko. Kiev. - pp. 16-18.

10. Pryshlyak, V.M. (2002) To build a mathematical model of movement on the sloping lands of a self-propelled machine with a stabilizing device, Bulletin of Agricultural Science of the Black Sea, Special Issue 4 (18), Volume II. - Mykolaiv: MSAU. - pp. 54-59.

11. Pugach, A.M. (2015) Integration processes in the field of agricultural education, science and production as a determining condition for the development of agricultural resource potential of Ukraine, Public Administration, Investments: practice and experience, № 13-14. - pp. 74-77. [Electronic resource]. - Access mode: http://www.investplan.com.ua/pdf/13-14_2015/20.pdf

12. Voznyuk, O.V. Pedagogical integration as one of the ways to build a holistic pedagogical paradigm. - Warsaw-Krakow, 2010. - pp. 72-80.

13. Law of Ukraine "On Higher Education" dated 01.07.2014 № 1556-VII / Newspaper "Voice of Ukraine" dated 06.08.2014 - № 148.

14. Chernilevsky D.V. (1995) Modern pedagogical technologies in higher school and their information and subject support // Modern pedagogical technologies in higher school. Vinnytsia: VDSGI. - pp. 3-10.

\section{Аннотация \\ Интеграция образования, науки и производства в системе подготовки агроинженеров к инновационной проектной деятельно- сти на основе учения акад. П.М. Василенко}

\section{В.М. Пришляк}

В статье освещены результаты научных исследований по разработке инновационных технологий подготовки будущих специалистов с агроинженерии к проектной деятельности. В соответствии с требованиями, установленными образовательными стандартами, в ходе исследования были выявлены и 
проанализированы основные факторы роста качественных показателей обучения и формирования профессиональных компетенций сельскохозяйственных инженеров. Установлено влияние, а также эффективность интеграции аграрного образования, науки и производства в системе подготовки агроинженеров к инновационной проектной деятельности на формирование профессиональных компетенций будущих специалистов, их знание теории рабочих процессов, необходимых для высокоэффективного функционирования агропромышленного производства, проведения научных исследований, направленных на совершенствование существующих и создание новых машин на основе учения акад. П.М. Василенко.

Процесс подготовки агроинженеров до проектной деятельности усложняется тем, что объектом роботы машин, орудий и механизмов аграрной отрасли являются объекты, материалы, среды с различными механико-технологическим, агротехническими и зооветеринарное свойствами. То есть, как правило, объектами являются биологически живые организмы, а поэтому переносить фооры и методы педагогических технологий из промышленности, машиностроения, строительной или транспортной инженерии иногда не эффективно и нецелесообразно. Нужны новые научные подходы с широкомасштабным привлечением научной составляющей, которые максимально ориентированы на объекты производственной деятельности будущих агроинженерних специалистов. Современный, подготовленный на научной основе, со знанием особенностей агропромышленного производства агроинженер - это ключевой субъект технического обеспечения технологических процессов растениеводства, животноводства и перерабатывающей отрасли.

Техническому обеспечению агропромышленного производства, особенно, творческой проектной деятельности П.М. Василенко уделял большое значение. Он считал, что первоочередным в проектировании и конструировании машин должны быть фундаментальные знания с технологий земледелия, агрофизических и механико-технологических свойств сельскохозяйственных материалов как объектов, с которыми взаимодействуют рабочие органы машин, изменяя их состояние, характеристики, положение и тому подобное. Интеграция аграрного образования, науки и производства в системе подготовки агроинженеров к инновационной проектной деятельности на основе учения акад. П.М. Василенко положительно влияет на формирование профессиональных компетенций будущих специалистов агропромышленного комплекса. Именно из-за такой кооперации возможен существенный рост валового национального продукта, увеличение и расширение экспортного потенциала страны, улучшение фиинансово-экономического и социального уровня жизни людей.

Ключевые слова: интеграция, образование, наука, производство, проектная деятельность.

\section{Abstract \\ Integration of education, science and production in the system of preparation of agricultural engineers for innovative project activity on the basis of studies of acad. P.M. Vasilenko}

\section{V.M. Pryshliak}

The results of scientific researches of development of innovative technologies of preparation of future specialists in agrarian engineering for project activity are covered in the article. In accordance with the requirements stipulated by educational standards, the main factors for the growth of quality indicators of training and the formation of professional competencies of agricultural engineers were identified and analyzed during research. The influence, as well as the efficiency of integration of agrarian education, science and production in the system of training of agricultural engineers for innovative project activity on the formation of professional competencies of future specialists, their knowledge of the theory of work processes necessary for the highly efficient functioning of agro-industrial production, conducting scientific research and directed creation of new machines on the basis of the teaching of Acad. P.M. Vasilenko were found. The process of preparing the agroengineer for the project activity is complicated by the fact that the object of the machines, tools and mechanisms of the agricultural industry are objects, materials, environments with various mechanical, technological, agro-technical and zooveterinary properties. Modern, scientifically prepared, with knowledge of the characteristics of agro-industrial production agro-engineer is a key subject of technical support of technological processes of crop, livestock and processing industry.

P.M. Vasilenko attached great importance to the technical support of agro-industrial production, especially creative design activities. He believed that fundamental knowledge on agricultural technologies, the agrophysical and mechanical-technological properties of agricultural materials as objects with which the working bodies of machines interact, changing their condition, characteristics, and positions should be of primary importance 
in the design and construction of machines. Integration of agrarian education, science and production in the system of preparation of agricultural engineers for innovative project activity on the basis of the teaching of acad. P.M. Vasylenko has a positive influence on the formation of professional competencies of future specialists of the agro-industrial complex. Thanks to such cooperation, a substantial increase in gross national product, an increase and expansion of the country's export potential, and an improvement in the financial, economic, and social living standards of people are possible.

Keywords: integration, education, science, production, project activity.

\section{Бібліографічне посилання/ Bibliography citation: Harvard}

Pryshliak, V.M. (2020). Integration of education, science and production in the system of preparation of agricultural engineers for innovative project activity on the basis of studies of acad. P.M. Vasilenko Engineering of nature management, (2(16), pp. 84 - 92.

Подано до редакції / Received: 02.08.2020 